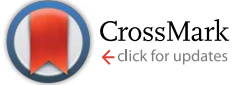

Cite this: RSC Adv., 2016, 6, 88216

Received 5th July 2016

Accepted 30th August 2016

DOI: 10.1039/c6ra17261j

www.rsc.org/advances

\section{Hypoallergenic acid-sensitive modification preserves major mugwort allergen fold and delivers full repertoire of MHC class II-binding peptides during endolysosomal degradation $\uparrow$}

\author{
Dragana Stanic-Vucinic, ${ }^{a}$ Marija Stojadinovic, ${ }^{\text {ab }}$ Ivana Mirkov, ${ }^{c}$ Danijela Apostolovic, ${ }^{d}$ \\ Lidija Burazer, ${ }^{\text {e }}$ Marina Atanaskovic-Markovic, ${ }^{\text {fg }}$ Milena Kataranovski ${ }^{\text {ch }}$ \\ and Tanja Cirkovic Velickovic *aij
}

\begin{abstract}
Modified allergens are a safer and more efficient alternative to natural allergens for specific immunotherapy. As the modification of an allergen can diminish its immunogenicity due to the alteration of $\mathrm{T}$-cell epitopes, in this paper we study the effects of a reversible chemical modification of Art $v 1$, the main allergen of mugwort pollen, on its allergenicity and immunogenicity. Modification of Art $v 1$ by cis-aconitylation into a polyanionic derivative (CAA) did not result in any significant structural alteration. However, IgE-binding epitopes on CAA were blocked, resulting in a reduced IgE-binding and basophil activation. Both proteins induced proliferation of $\mathrm{CD}^{+} \mathrm{CD}^{+} \mathrm{T}$-cells in mugwort-allergic patients, but only unmodified allergens increased IL-4, IL-5 and IL-10 production. Rabbit and mouse anti-CAA antibodies exhibited crossreactivity with native allergens and blocked human IgE-binding to Art $\vee 1$. Degradation of CAA by lysosomal fraction enzymes resulted in a similar set of peptides, harboring MHC class II-binding peptides, as unmodified proteins. Thus, cis-aconitylation modified Art $v 1$ had a significantly reduced allergenicity, whereas its immunogenicity was completely preserved. Acid-environment-responsive modification, which releases a full repertoire of native allergen epitopes within a particular site, can be considered a smart drug delivery system, which is able to deliver a therapeutically-effective dose in a controlled manner, and minimizes adverse side effects.
\end{abstract}

\section{Introduction}

Allergen-specific immunotherapy (ASIT) is the only desensitizing therapy for IgE-mediated allergic diseases that aims at modifying the underlying immune mechanism. The modes of action of AIT include the induction of early desensitization of

${ }^{a}$ University of Belgrade, Faculty of Chemistry, Center of Excellence for Molecular Food Sciences, Department of Biochemistry, Studentski trg 16, 11000 Belgrade, Serbia. E-mail: tcirkov@chem.bg.ac.rs; Fax: +381 11333 6608; Tel: +381 113336608

${ }^{b}$ University of Belgrade, Faculty of Chemistry, Department of Biochemistry, Studentski trg 16, Belgrade, Serbia

"Institute for Biological Research "Sinisa Stankovic", University of Belgrade, Bulevar despota Stefana 142, Belgrade, Serbia

${ }^{d}$ Innovation Center, Faculty of Chemistry Ltd, Studentski trg 16, Belgrade, Serbia ${ }^{e}$ Institute of Virology, Vaccines and Sera - Torlak, Vojvode Stepe 458, Belgrade, Serbia ${ }^{f}$ University Children's Hospital "Tirsova”, Department of Allergology and Pulmology, University of Belgrade, Tirsova 10, Belgrade, Serbia

${ }^{g}$ University of Belgrade, School of Medicine, Dr Subotica 8, Belgrade, Serbia ${ }^{h}$ University of Belgrade, Faculty of Biology, Studentski trg 16, Belgrade, Serbia ${ }^{i}$ Ghent University Global Campus, Incheon, Korea ${ }^{j}$ Ghent University, Faculty of Bioscience Engineering, Ghent, Belgium

$\dagger$ Electronic supplementary information (ESI) available. See DOI: 10.1039/c6ra17261j mast cells and basophils; generation of regulatory T- and B-cell responses; regulation of IgE and IgG4 levels; reduction in numbers and activity of eosinophils and mast cells in mucosal tissues; and bringing about a decrease in the activity of basophils in circulation. Skewing of allergen-specific effector T- and B-cell responses to a regulatory phenotype appears to be a key event in the course of AIT. ${ }^{1}$

Current ASIT protocols are long and have a risk of anaphylactic reactions when native allergens are used. Therefore, current research is aimed at decreasing the risk of side effects while maintaining or improving the efficacy of ASIT. ${ }^{2}$

Different strategies for increasing the safety and efficacy of immunotherapies are under development and these strategies target B-cells, T-cells or antigen-presenting cells (APCs). Hypoallergenic recombinant variants of major allergens aim at reducing side-effects of IgE-mediated reactions, while inducing T-cell tolerance and generation of IgG4 blocking antibodies. ${ }^{2,3} \mathrm{~T}$ Cell peptides of allergens that are devoid of conformational B-cell epitopes, but long enough to bind to T-cell receptors, are examined for induction of tolerance. ${ }^{4}$ Small peptides representing minor B-cell epitopes fused to an immunogenic carrier protein aim at inducing blocking antibodies against conformational 
epitopes, but without the activation of allergen-specific T-cells. ${ }^{3}$ In addition, there are strategies that aim at dendritic cells (DCs) and endolysosomal compartments (ELC) of APCs in particular, i.e. the so-called LAMP-vax ${ }^{\mathrm{TM}}$ DNA vaccines, which produce the encoded allergen sequence inside the cell as part of a fusion protein, with a lysosomal-associated membrane protein (LAMP) ${ }^{3}$ and neoglycoallergens are delivered to dendritic cells via specific receptors. ${ }^{5}$

Among different approaches for AIT improvement, the use of chemically modified hypoallergenic derivatives stands out as a clinically effective strategy that has been proven in doubleblind placebo-controlled studies for decades. ${ }^{6}$ Ideally, a modified allergen suitable for use in AIT should have its IgE binding epitopes destroyed by modification in order to diminish (or reduce) IgE-binding and IgE-mediated side effects, while structural motifs necessary for T-cell recognition should be preserved. Since many of the B- and T-cell epitopes in allergens are virtually identical, or shared, chemical modification in an uncontrollable manner inevitably destroys certain T-cell epitopes and may lead to a reduced or even diminished capacity for a modified protein to induce allergen-specific immune responses. ${ }^{4-7}$

In this study we tested a hypothesis that an acid-sensitive polyanionic derivative of a pollen allergen will generate a full repertoire of native $\mathrm{B}$ - and T-cell epitopes during acidification in ELC and efficiently raise cross-reactive antibodies to the native protein (blocking antibodies), while also bypassing IgE-mediated reactions of effector cells due to masking of the IgE-epitopes. Our approach included modification of the major mugwort pollen allergen, Art v $1{ }^{7}$ by an acid-sensitive modification: cis-aconitylation of lysine $\varepsilon$-amino groups in the protein., ${ }^{\mathbf{8} 9}$

We demonstrated that our approach created a hypoallergenic protein with a fully preserved fold and intact repertoire of T-cell epitopes. Profiling endolysosomal degradation of proteins in APCs by mass spectrometry identified Art v 1-derived peptides and proved the controlled delivery of a full repertoire of T-cell epitopes in ELC.

\section{Materials and methods}

\section{Preparation and modification of Art $\mathbf{v} 1$}

Art v 1 was isolated from a pollen extract of Artemisia vulgaris by ion-exchange HPLC and modified by cis-aconitylation according to a previously described protocol. ${ }^{9}$ Briefly, Art v $1\left(1.5 \mathrm{mg} \mathrm{mL}^{-1}\right)$ in $4 \% \mathrm{NaHCO}_{3}$ was treated with the bolus addition of cis-aconitic anhydride (Sigma-Aldrich, Steinheim, Germany) with extensive mixing at $4{ }^{\circ} \mathrm{C}$. The final anhydride concentration was $400 \mathrm{mM}$. After every bolus addition, the $\mathrm{pH}$ was adjusted to 9.0 with solid $\mathrm{Na}_{2} \mathrm{CO}_{3}$. The mixture was extensively dialyzed against phosphate buffered saline (PBS) for $20 \mathrm{~h}$ at $4{ }^{\circ} \mathrm{C}$. All samples were stored at $-20{ }^{\circ} \mathrm{C}$ until use. Concentrations of native and modified proteins were determined spectrophotometrically at $280 \mathrm{~nm}$ using an extinction coefficient of $640 \mathrm{~mL} \mathrm{mg}^{-1} \mathrm{~cm}^{-1}$, calculated for Art v 1 as described previously. ${ }^{10}$

The obtained cis-aconitylated Art v 1 (CAA) had approximately $80 \%$ modified amino groups, dramatically reduced pI and low stability in acidic conditions. ${ }^{9}$

\section{CD spectrometry and fluorimetry measurements}

Far UV CD spectra were recorded on a JASCO J-815 spectropolarimeter (JASCO, Japan) with Art $\mathrm{v} 1$ and CAA at a concentration of $1 \mathrm{mg} \mathrm{mL} \mathrm{mL}^{-1}$ in PBS. Each spectrum was acquired four times, and the results were averaged. Results were expressed as a residue-average molar ellipticity as follows: $[\theta]=$ $\theta /(10 \times n \times C \times d)$, where $\theta$ is the measured ellipticity, $n$ is the number of Art v 1 amino acid residues, $C$ is the molar concentration of the Art v 1 sample, and $d$ is the path length of the cell. Spectra were analyzed by CONTIN software to determine the percentage of $\beta$-sheet, $\alpha$-helical and random coil structures using the CDPro software package (http://lamar.colostate.edu/ $\sim$ sreeram/CDPro/main.html). For the calculations, a reference protein base set, SP37, was used.

Fluorescence measurements were performed using a Horiba Scientific Fluoromax-4 Spectrofluorometer (Horiba, Kyoto, Japan). For intrinsic tryptophan fluorescence measurements Art $\mathrm{v} 1$ samples were diluted in $10 \mathrm{mM}$ potassium phosphate buffer ( $\mathrm{pH}$ 6.5) to give a final concentration of $0.5 \mu \mathrm{M}$ and emission spectra were recorded with an excitation wavelength of $280 \mathrm{~nm}$ (5 nm slit width). For hydrophobic ligand binding experiments, the fluorescence spectra of the Art v 1 solutions $(16 \mu \mathrm{M}$ in 10 $\mathrm{mM}$ potassium phosphate buffer $\mathrm{pH}$ 6.5) saturated using $80 \mu \mathrm{M}$ of 8-anilino-1-naphthalenesulfonic acid (ANS, Sigma-Aldrich) in $10 \mathrm{mM}$ sodium phosphate buffer $\mathrm{pH} 8$ were recorded with an excitation wavelength of $350 \mathrm{~nm}$.

\section{Immunization of rabbits and determination of specific IgG antibody levels by ELISA}

The animals were treated according to Directive 2010/63/EU of the European Parliament and the Council of 22 September 2010 on the protection of animals used for scientific purposes. All animal procedures were approved by the Ethical Committee for the Use of Laboratory Animals of the Institute for Biological Research "Siniša Stanković”, University of Belgrade (No. 2-20/ 10).

The antibodies against Art v 1, CAA and irrelevant proteins (kiwi fruit protein extract) were raised in rabbits according to Harboe \& Ingild ${ }^{\mathbf{1 1}}$ and as previously described for acetylated Art v 1. ${ }^{12}$ All experiments were approved by the Ethics Committee for Animal Experimentation at Belgrade University. Two rabbits were immunized subcutaneously with each of the two proteins and the serum obtained by pooling serum specimens of two rabbits was used for experiments. Before the first immunization, serum samples were taken as the reference point, and then every 2 weeks after 51 days from the start of immunization. For direct ELISA, Art v 1 and CAA were coupled to the microtiter plates (Nunc, MaxiSorp, Roskilde, Denmark, $5 \mu \mathrm{g} \mathrm{mL}^{-1}$ ) and the total IgG levels were determined by ELISA using anti-rabbit IgG (whole molecule) alkaline phosphatase (AP) labeled antibodies (Sigma-Aldrich) and 4-nitrophenyl phosphate (4-NPP, SigmaAldrich) as the substrate. Rabbit serum was diluted $1: 100$ in a diluting buffer consisting of $0.5 \%$ BSA in Tris-buffered saline ( $\mathrm{pH}$ 7.4) containing $0.05 \%$ Tween-20 (TTBS), and then double fold serial dilutions were performed in the same buffer. In total, 12 double fold serial dilutions were done. A control series was 
done on the same plates with the rabbit antiserum raised against kiwi fruit extract proteins. Absorbance was measured at $405 \mathrm{~nm}$ after adjusting the background with the negative control. Samples were measured and mean values of the two replicas were presented.

\section{Human sera}

Sera from 13 patients with a positive skin prick test to mugwort pollen, a documented clinical history of a mugwort pollen allergy and with no previous immunotherapy to mugwort pollen, were used for ELISA inhibition and blocking experiments. Fresh heparinized blood was used for basophil activation and lymphocyte proliferation assay. Informed consent was obtained before the start of the study from all patients for their sera to be used for research purposes. The study was approved by the Ethical Committee of the University Children's Hospital, Belgrade, Serbia (No. 017/6-990/66), and was performed in compliance with the Declaration of Helsinki.

\section{Inhibition of human IgE and rabbit IgG binding in ELISA assay by Art $v 1$ and CAA}

The microtiter plates were coated with $50 \mu \mathrm{L}$ of Art $\mathrm{v} 1(5 \mu \mathrm{g}$ $\mathrm{mL}^{-1}$ in $0.1 \mathrm{M}$ carbonate buffer, $\mathrm{pH}$ 9.6) overnight and washed with TTBS. After blocking with $100 \mu \mathrm{L}$ of $1 \%$ BSA in TTBS, $50 \mu \mathrm{L}$ of an individual's human sera, previously incubated with $50 \mu \mathrm{L}$ of serially 10-fold diluted Art v 1 or CAA in tubes for 30 min at 4 ${ }^{\circ} \mathrm{C}$, were added to the plates. Human serum pool was used at a dilution sufficient to achieve $80 \%$ of IgE binding to the coupled antigen, as determined in a separate ELISA. For inhibition, serial dilutions of unmodified and modified Art v 1 were prepared in a buffer consisting of TTBS- $0.5 \%$ BSA. The remaining unbound $\mathrm{IgE}$ that binds to the Art $\mathrm{v} 1$ coupled plate was detected using anti-human IgE antibodies labeled with AP (Sigma-Aldrich) and 4-NPP as the substrate. Absorbance was measured at $405 \mathrm{~nm}$ after adjusting the background with the negative control. The percentage of inhibition was calculated as follows: $\%$ inhibition $=(\mathrm{OD}$ of the test sample $-(\mathrm{OD}$ of the inhibited sample/OD of the test sample sample) $) \times 100$. The test sample (positive control) was $50 \mu \mathrm{L}$ of the two-fold diluted human serum incubated with $50 \mu \mathrm{L}$ of diluting buffer. All steps were performed at room temperature. ELISA inhibition with rabbit sera (5000 times diluted) was done in the same way and detection was done with anti-rabbit IgG antibodies labeled with AP.

\section{Competition ELISA for assessment of blocking human IgE antibody}

The microtiter plates were coated with Art v $1\left(5 \mu \mathrm{g} \mathrm{mL} \mathrm{L}^{-1}\right)$. After blocking with $1 \%$ BSA in TTBS, the plates were pre-incubated (1:1) with serial dilutions (4 to 1024) of rabbit antibodies generated to Art v 1 and CAA during $30 \mathrm{~min}$. Two rabbits were immunized with each protein and the serum obtained by pooling serum specimens of two rabbits was used for experiments. After that, pooled sera of mugwort pollen allergic patients, which were 1.5 times diluted, were incubated for 90 min and the remaining unblocked IgE that binds to the Art v 1 coupled to the plate was detected using antihuman IgE antibodies labeled with AP.

\section{Lymphocyte proliferation assay in human peripheral blood mononuclear cell (PBMC) cultures}

PBMCs were obtained from the heparinized venous blood of 10 mugwort-allergic patients and cultured exactly according to Perovic et al. ${ }^{12}$ Stimulation of the PBMCs with allergens and a lymphocyte proliferation assay were done as described. ${ }^{12}$ The PBMCs were stimulated for 7 days with Art v 1, CAA $\left(10 \mu \mathrm{g} \mathrm{mL}^{-1}\right)$ or unstimulated with medium alone in duplicates. Tetanus toxoid (TT) (5 mg mL $\mathrm{m}^{-1}$, Torlak, Serbia) was used as a positive control. As a measure of stimulation, the number of proliferating $\mathrm{CD}^{+} \mathrm{CD}^{+}$cells $\left(\mathrm{CD} 3^{+} \mathrm{CD} 4^{+}\right.$cells among gated blasts) is expressed as the number of proliferating cells per 100000 lymphocytes (resting and proliferating lymphocytes). Supernatants, collected for determination of cytokines (IL-2, IL-4, IL-5, IL-10, TNF- $\alpha$ and IFN- $\gamma$ ), were analyzed using the Th1/Th2 cytometric bead array-kit (BD Biosciences) according to the manufacturer's instruction.

\section{Basophil activation assay}

The expression of CD203c was performed as previously described. ${ }^{12}$ Briefly, heparinized blood samples were taken from three mugwort-allergic patients. Blood aliquots $(100 \mu \mathrm{L})$ were incubated with dilutions of Art $\mathrm{v} 1$ and CAA $\left(10^{-6}, 10^{-5}, 10^{-4}\right.$, $10^{-3}, 10^{-2}$ and $0.1 \mu \mathrm{g} \mathrm{mL}{ }^{-1}$ ), anti-IgE antibody was taken as a positive control $\left(1 \mu \mathrm{g} \mathrm{mL}{ }^{-1}\right)$, or PBS as a negative control for 15 $\min \left(37^{\circ} \mathrm{C}\right)$. After incubation, cells were washed in PBS and then incubated with $10 \mu \mathrm{L}$ of phycoerythrin (PE)-labelled CD203c monoclonal antibody (Beckman Coulter, USA) and fluoresceinisothiocyanate (FITC)-labelled CD63 monoclonal antibody (Beckman Coulter) for $15 \mathrm{~min}$ at room temperature. Thereafter, samples were subjected to erythrocyte lysis with $2 \mathrm{~mL}$ of FACSTM lysing solution (BD Biosciences, USA). Cells were then washed, resuspended in PBS, and analysed by flow cytometry using a FACSCalibur (BD Biosciences). The magnitude of basophil activation was calculated as the percentage of $\mathrm{CD}^{+} 3^{+}$events among the gated basophils $\left(\mathrm{CD} 3^{+} \mathrm{CD} 203 \mathrm{c}^{+}\right)$.

\section{Immunization of mice and determination of specific antibody responses in ELISA assay}

The age-matched (eight-week-old) male C57BL/6 mice were used in the experiments. The animals were obtained from our own animal facility at the Institute for Biological Research "Sinisa Stankovic" (Belgrade, Serbia). Mice (seven mice per group) were immunized (i.p.) for 6 weeks with $100 \mu \mathrm{g}$ of Art v 1 or CAA adsorbed onto $200 \mu \mathrm{L}$ of alum $\left(0.4 \% \mathrm{Al}(\mathrm{OH})_{3}\right)$ per immunization. Control groups were immunized with $200 \mu \mathrm{L}$ of alum and PBS instead of allergens. Alum was prepared according to the method reported by Gupta. ${ }^{13}$ Immunizations and bleedings were done at two week intervals (day 0, 14 and 28). Final bleeding was done on day 42 . Sera were stored at -80 ${ }^{\circ} \mathrm{C}$ until analysis. IgE, total IgG, IgG1, IgG2a and IgG2b responses were measured by ELISA. 
ELISA plates were coated with $100 \mu \mathrm{L}$ per well of allergens (5 $\mu \mathrm{g} \mathrm{mL}^{-1}$ in PBS) overnight. After washing with TBS-0.05\% Tween plates were blocked for 90 min with 1\% BSA in TTBS and mice sera $(100 \mu \mathrm{L}$ per well) diluted in TTBS-1\% BSA were added (IgE, $1: 3$; IgG2a, $1: 10$; IgG2b, $1: 10$, IgG1, $1: 300$; and total IgG, $1: 300$ ). In parallel, positive anti-Art $\mathrm{v} 1$ serum pool was serially diluted in order to estimate specific antibody arbitrary units, as previously described. ${ }^{\mathbf{1 4}}$ The plates were incubated with sera in duplicate overnight at $4{ }^{\circ} \mathrm{C}$ and washed three times in TTBS. Bound mouse antibodies were detected after $3 \mathrm{~h}$ of incubation with $100 \mu \mathrm{L}$ of biotin-labeled monoclonal antimouse IgE, anti IgG1, IgG2a and IgG2b antibodies (BioLegend, San Diego, CA) diluted in TTBS-1\% BSA $\left(1 \mu \mathrm{g} \mathrm{mL}^{-1}\right)$ and alkaline phosphatase-labeled goat anti-mouse IgG diluted $1: 15000$ (Sigma-Aldrich). After washing with TTBS three times, avidin-AP (Sigma-Aldrich) or AP-labeled anti-goat IgG (SigmaAldrich) was added and maintained for $2.5 \mathrm{~h}$. The plates were again washed three times with TTBS and 4-NPP was added as the substrate.

\section{Endolysosomal degradation assay and peptide analysis following mass spectrometry}

A microsomal fraction was isolated from BALB/c DCs by differential centrifugation and characterized as described previously. ${ }^{\mathbf{1 4}}$ Endolysosomal degradation assays were performed with $0.25 \mathrm{mg} \mathrm{mL}^{-1}$ of Art v 1 and CAA and $0.4 \mathrm{mg} \mathrm{mL}^{-1}$ of isolated microsomal proteins in a final volume of $20 \mu \mathrm{L}$, containing $100 \mathrm{mM}$ citrate buffer, $\mathrm{pH} 4.8$, and $2 \mathrm{mM}$ dithiothreitol (DTT). Reactions were conducted for $15 \mathrm{~min}, 3$, 12, 24, and $48 \mathrm{~h}$ at $37{ }^{\circ} \mathrm{C}$ and stopped by boiling for $5 \mathrm{~min}$ at $95{ }^{\circ} \mathrm{C}$ followed by freezing at $-20{ }^{\circ} \mathrm{C}$. Digests were analyzed by SDSPAGE according to the method reported by Laemmli $^{15}$ on a $12 \%$ polyacrylamide gel with a standard protein mixture (Sigma-Aldrich) for a molecular weight reference. Gels were stained with Coomassie brilliant blue R-250 (Sigma-Aldrich). The bands obtained were quantitatively evaluated by densitometry.

For mass spectrometry analysis, the samples were diluted ten times with a $1 \%$ solution of formic acid. Peptides were analyzed on an EASY nLC II system coupled with a LTQ Orbitrap XL (Thermo scientific Inc., MA, USA) previously calibrated with the ProteoMass ${ }^{\mathrm{TM}}$ LTQ/FT-Hybrid ESI Positive Mode Cal Mix (MSCAL5 SUPELCO, Sigma Aldrich) calibration set. In total, 240 $\mathrm{ng}$ of proteins were injected onto the EASY-Spray PepMap C18 Column $(150 \times 0.075 \mathrm{~mm}, 3 \mu \mathrm{m}$ particle size $)$. Solvent A was a $0.1 \%$ formic acid aqueous solution and solvent $\mathrm{B}$ was $0.1 \%$ formic acid in acetonitrile. A 50 min gradient from $5-70 \%$ of solvent B was applied using a $300 \mathrm{~nL} \min ^{-1}$ flow rate. The CID normalized collision energy value was $35.0 \%$. Parameters for Nanoelectro Spray Ionization (NSI) were as follows: spray voltage $+3.91 \mathrm{kV}$, capillary voltage $6 \mathrm{~V}$, capillary temp $275^{\circ} \mathrm{C}$, tube lens $100 \mathrm{~V}$. Spectra were recorded in positive mode in the range of $\mathrm{m} / \mathrm{z} 500-3000$. The five most intense monoisotopic peaks in the spectra were fragmented using collision-induced dissociation and measured in the linear ion trap.
Predictions of the peptide sequences were done using the exact masses obtained using MS, exact masses of the native isoforms (Uniprot Q84ZX5) and the peptide calculator tool (http://pepcalc.com/). For the theoretical mass calculations in the peptide calculator, the amino acid sequence for Art $v 1$ (Uniprot Q84ZX5) was used. To take into account posttranslational modifications, mass additions of $16 \mathrm{Da}$ for the hydroxylation of proline, 2, 4, 6 or 8 Da for partial reduction, as well as 162 Da for galactose and 132 Da for arabinose were used.

The digestion resistant peptides of Art v 1 were modeled in the Modeller software (http://salilab.org/modeller/) based on the NMR solved structure of Art v 1, pdb 2KPY. ${ }^{16}$

\section{Statistics}

For all experiments, differences were compared statistically using the Wilcoxon matched pairs test and the Statistica 9.0 program, except for the analysis of the $\mathrm{IC}_{50}$ values in the ELISA inhibition assay of IgE binding by Art $\mathrm{v} 1$ and CAA, in which a paired sample $t$-test $(P<0.05)$ was used.

\section{Results}

\section{Extensive cis-aconitylation of Art $\mathrm{v} 1$ does not change protein folding}

Following the modification of lysine residues, approximately $80 \%$ of the positively charged amino groups in the protein were replaced by double-negative groups of cis-aconitic acid. A significant repulsion between the highly charged surface residues, particularly in the lysine-rich defensin globe of Art v 1, ${ }^{17}$ may result in a partial unfolding of the protein. Thereby, the Art v 1 and CAA secondary and tertiary structures by circular dichroism, Trp emission fluorescence and ANS binding were probed.

CD spectra were obtained for both proteins with a negative peak at $203 \mathrm{~nm}$ (Fig. 1A), which is in accordance to previous findings. ${ }^{17,18}$ We calculated the $\%$ of $\alpha$-helix, $\beta$-sheet, $\beta$-turn and random coil (Fig. 1B). The secondary structure content of Art v 1 was virtually unaffected by the modification.

In order to get insight into the tertiary structure changes induced by cis-aconitylation, intrinsic tryptophan fluorescence emission spectra were examined (Fig. 1C). When excited at 280 $\mathrm{nm}$, native Art $\mathrm{v} 1$ exhibited a fluorescence emission maximum $\left(\lambda_{\max }\right)$ at $352 \mathrm{~nm}$, originating from the only solvent exposed tryptophan residue (Trp 29) located in the defensine domain. A decrease in intensity was observed due to the quenching of the tryptophan fluorescence by the charged cis-aconityl groups. However, negligible red shifting of the $\lambda_{\max }$ to $353 \mathrm{~nm}$ and the fluorescence spectra retaining the overall shape in CAA indicates that cis-aconitylation only slightly disrupted the Art v 1 tertiary structure.

Upon non-covalent binding of the polarity-sensitive hydrophobic fluorescent probe ANS to hydrophobic patches on the protein surfaces, the fluorescence intensity increases and the wavelength of emission maximum demonstrates a blue shift. The decreased ANS binding to CAA with a red shift (from 471 to $475 \mathrm{~nm}$ ) reflects a higher degree of accessibility for water 


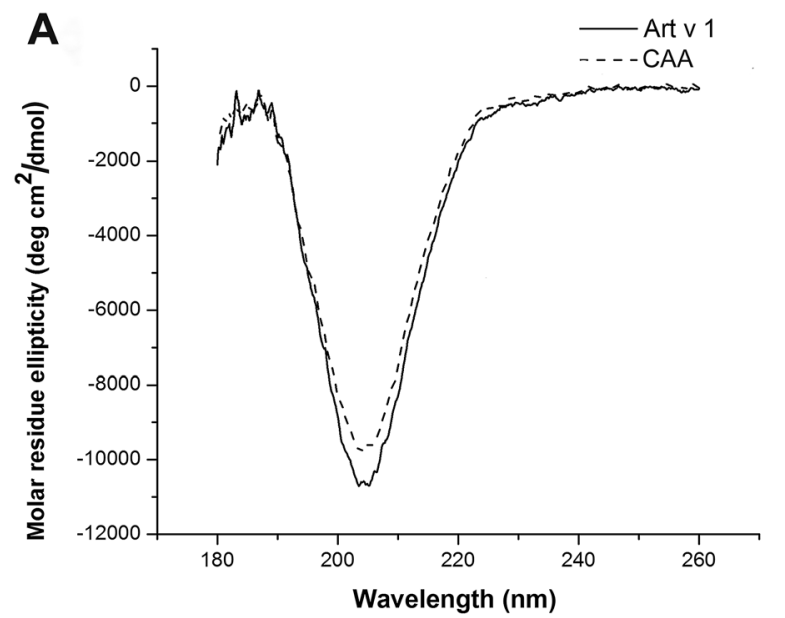

B
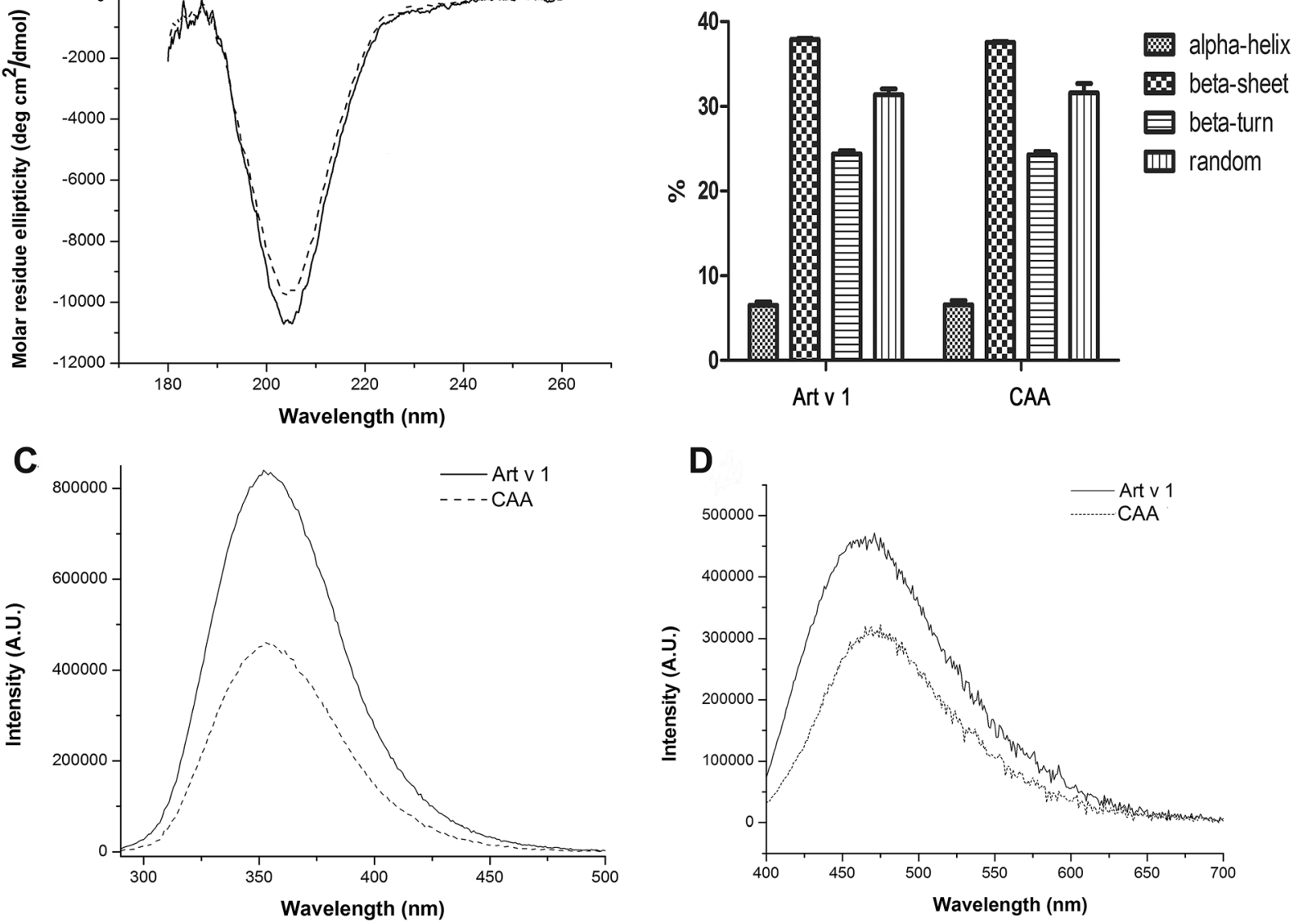

Fig. 1 Secondary and tertiary structural properties of native and cis-aconitylated Art v 1. (A) Far UV CD spectra of Art v 1 and CAA (1 mg mL ${ }^{-1}$ in PBS pH 7.2), (B) calculated content of the secondary structure fractions, (C) intrinsic tryptophan fluorescence emission spectra of Art $v 1$ and CAA $(0.5 \mu \mathrm{M}$ in $10 \mathrm{mM}$ potassium phosphate buffer, $\mathrm{pH}$ 6.5) when excited at $280 \mathrm{~nm}$ (D) binding of polarity-sensitive hydrophobic fluorescent probe ANS $(80 \mu \mathrm{M})$ to hydrophobic patches on protein surfaces of native and cis-aconitylated Art $v 1$ (16 $\mu \mathrm{M}$ in $10 \mathrm{mM}$ potassium phosphate buffer $\mathrm{pH}$ 6.5).

molecules to the ANS binding region within CAA, indicating that modified Art v 1 has slightly less hydrophobic surfaces (Fig. 1D). These results suggest that cis-aconitylation did not substantially disturb the secondary and tertiary structure of Art $\mathrm{v} 1$, in spite of the fact that Art $\mathrm{v} 1$ was extensively modified by acylation.

\section{cis-Aconitylation masks the surface of Art $\mathrm{v} 1$ and reduces specific IgG and IgE binding}

To investigate whether the modification of Art $\mathrm{v} 1$ altered protein epitopes, we first raised antibodies against Art $v 1$ in rabbits and analyzed the inhibitory potential of Art $v 1$ and CAA for rabbit anti-Art v 1 IgG binding to an Art v 1 coupled plate (Fig. 2A). The $\mathrm{IC}_{50}$ values for Art v 1 and CAA were 0.09 and 15.85 $\mu \mathrm{g} \mathrm{mL}^{-1}$, respectively, and with inhibitor concentration of 100 $\mu \mathrm{g} \mathrm{mL}^{-1}$, an inhibition of $100 \%$ was achieved for Art $\mathrm{v} 1$, whereas an inhibition of only $60 \%$ was achieved for CAA. This implies that the introduced acyl groups masked the Art v 1 epitopes so that they are weakly recognized by Art v 1 specific antibodies.
$\mathrm{IC}_{50}$ values obtained for the inhibition of human IgE binding to Art v 1 (Fig. 2B) with 13 individual sera from mugwort pollen allergic patients were consistent with the aforementioned result. The $\mathrm{IC}_{50}$ values for Art $\mathrm{v} 1$ and CAA were in the range from 0.001 to $0.656 \mu \mathrm{g} \mathrm{mL} \mathrm{mL}^{-1}$ (mean $=0.071$ ), and 0.318 to $22.656 \mu \mathrm{g} \mathrm{mL}^{-1}$, respectively. For all tested sera, the $\mathrm{IC}_{50}$ values increased from 10 to 575 -times (mean $=188, n=13$ ) for CAA compared to Art v 1. This result indicates that the IgE binding epitopes in CAA were significantly altered and cis-aconitylation significantly $(p<0.05)$ reduced the Art $v 1$ allergenic potency in the tested group of mugwort-allergic patients.

A significant alteration in the IgE-binding epitopes of CAA also resulted in its reduced ability to degranulate effector cells in the three mugwort pollen-allergic patients. In comparison to Art v 1, a higher concentration of CAA was needed to induce upregulation of CD63 on $\mathrm{CD} 203 \mathrm{c}+$ cells of allergic donors (Fig. 2C). In one of the tested allergic donors (Fig. 2C, \#3), CAA did not induce a significant degranulation of basophils, even at the highest concentration that was tested. These results indicate that IgG and IgE epitopes of Art v 1 were significantly 

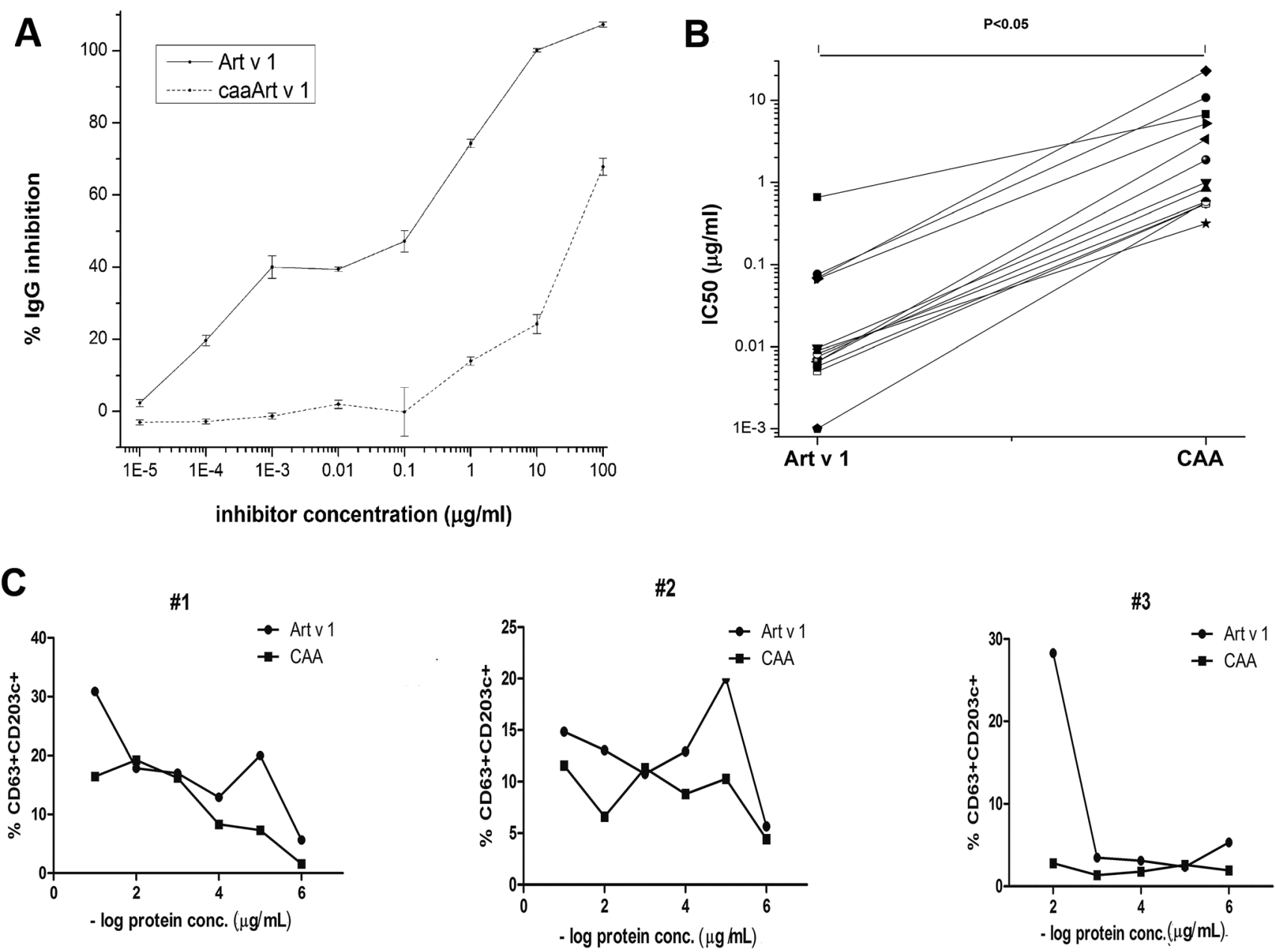

Fig. 2 IgG and IgE binding properties of native and modified Art v 1. (A) ELISA inhibition of IgG binding to the Art $v 1$ coupled to the plate by rabbit sera immunized by Art v 1 or CAA. Rabbit sera, previously incubated with serially 10 -fold diluted Art v 1 or CAA, were added to the plates and the remaining unbound IgG that binds to the Art v 1 coupled plate was detected. (B) Analysis of IC50 ( $\mu \mathrm{g} \mathrm{mL} \mathrm{m}^{-1}$ ) values obtained using an ELISA inhibition assay of IgE binding from 13 individual mugwort pollen allergic patients' sera by Art $v 1$ and CAA. Individual human sera, previously incubated with serially 10 -fold diluted Art $v 1$ or CAA, were added to the plates and the remaining unbound IgE that binds to the Art $v 1$ coupled plate was detected. Increase in $I C_{50}$ value corresponds to a decrease in IgE-binding capacity $(P<0.05$, paired sample $t$-test). (C) Basophile activation test in three representative mugwort pollen-allergic patients measured with six different concentrations of Art $v 1$ and CAA. Anti-IgE antibody was used as a positive control.

modified in CAA which results in a reduced ability to degranulate effector cells.

\section{$\mathrm{CD}^{+} \mathrm{T}$-cells proliferation and cytokine response to Art $\mathrm{v} 1$ and CAA in PBMC cultures of mugwort-allergic patients}

In order to characterize T-cell responses to modified Art $\mathrm{v} 1$, $\mathrm{CD}^{+}{ }^{+} \mathrm{CD} 4^{+}$cell proliferation and cytokine response to Art v 1 and CAA in PBMC, cultures of 10 mugwort-allergic patients were monitored (Fig. 3). T-Cell proliferation to Art v $1(p<0.05)$ and CAA $(p<0.05)$ was statistically significant when compared to unstimulated cells (Fig. 3A). The proliferating response to CAA did not differ from the response to Art v 1, suggesting that T-cell epitopes were preserved.

In response to Art $\mathrm{v} 1$ stimulation, increased amounts of IL-4 $(p<0.05)$, IL-5 $(p<0.05)$ and IL-10 $(p<0.01)$ were detected in donors (Fig. 4B-D). However, there were no statistically

\section{PBMC proliferation}

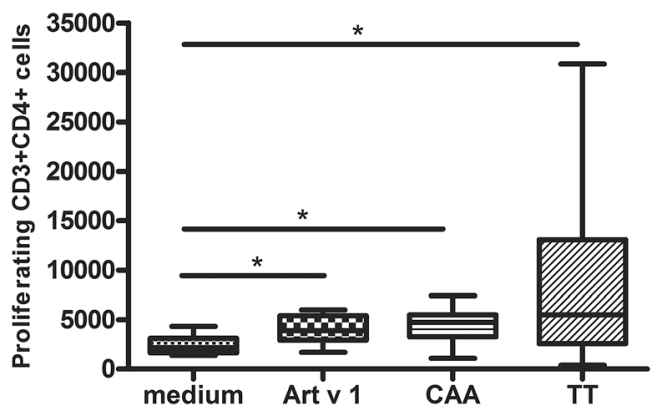

Fig. 3 Proliferation of $\mathrm{CD} 3^{+} \mathrm{CD} 4^{+}$cells in response to Art v $1, \mathrm{CAA}$ and tetanus toxoid (TT) in 10 mugwort pollen allergic donors' PBMC. The PBMCs were stimulated during 7 days with Art v 1 , CAA $\left(10 \mu \mathrm{g} \mathrm{mL}^{-1}\right)$, tetanus toxoid $\left(5 \mathrm{mg} \mathrm{mL}^{-1}\right)$ as a positive control, or were unstimulated (with medium alone). Statistical significance: ${ }^{*} p<0.05$. 

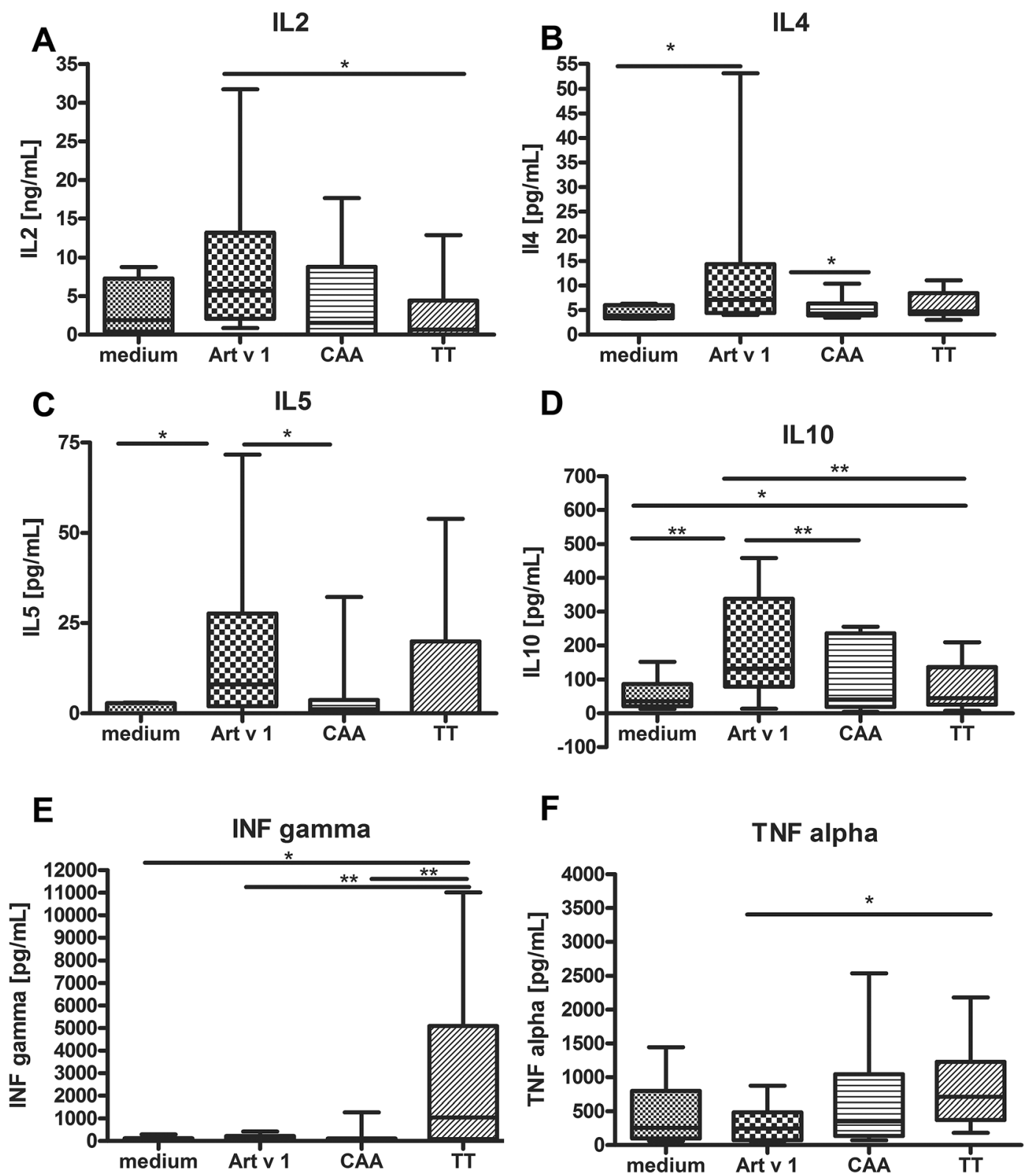

Fig. 4 Th1/Th2 type of cytokines induced in PBMC by stimulation with Art v 1, CAA and TT. The PBMCs were stimulated during 7 days with Art v 1 , CAA $\left(10 \mu \mathrm{g} \mathrm{mL}^{-1}\right)$, tetanus toxoid $\left(5 \mathrm{mg} \mathrm{mL}^{-1}\right)$ as a positive control, or were unstimulated (with medium alone). In collected supernatants, levels of secreted cytokines were determined: (A) IL-2, (B) IL-4, (C) IL-5, (D) IL-10, (E) IFN- $\gamma$ and (F) TNF- $\alpha$. Statistical significance: ** $p<0.005$ and * $p<$ 0.05 .

significant increases in IL-4, IL-5 and IL-10 production in the cytokine response to CAA, as compared to the unstimulated cultures. In addition, PBMC stimulated with CAA induced less IL-4 $(p<0.05)$, IL-5 $(p<0.05)$ and IL-10 $(p<0.01)$ than native Art v 1. Based on the cytokine profiles, it appears that cis-aconitylated Art v 1 stimulated a Th2-like cell response in PBMC to a much lower extent than Art $v$, although the number of $\mathrm{CD} 3^{+} \mathrm{CD} 4^{+}$ proliferating cells did not differ significantly.

\section{CAA raises anti-Art $v 1$ antibodies in rabbits}

For the evaluation of CAA capacity to induce an IgG response, rabbit sera obtained by immunization with native or modified
Art v 1 were tested in direct ELISA experiments. In direct ELISA anti-Art $\mathrm{v} 1$ and anti-CAA sera recognized Art $\mathrm{v} 1$ at almost the same extent (Fig. 5B). In contrast, when CAA was coupled to the plate, Art v 1-specific antibodies did not recognize epitopes on the modified protein, which is in accordance with data obtained in ELISA inhibition. However, the rabbit antibodies generated to the modified protein, recognized both the native and the modified protein (Fig. 5B). These results support our hypothesis that acylated Art $v 1$ can induce production of Art v 1 specific IgG antibodies of high specificity in vivo.

To investigate the potential to block allergen-specific IgE, rabbit IgG antibodies generated to Art v 1 and CAA were tested 
A

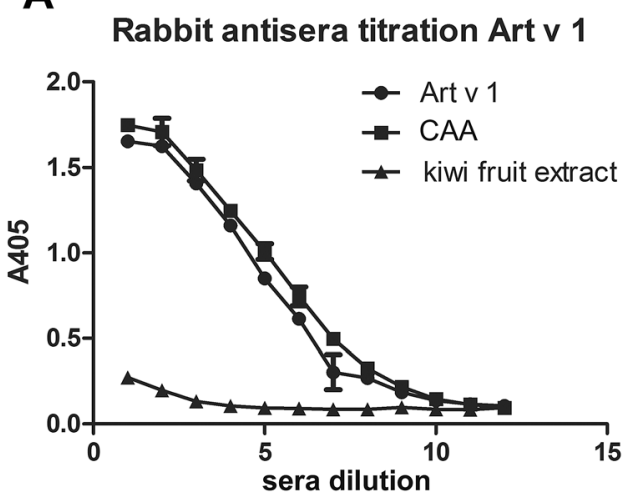

B

Rabbit antisera titration CAA

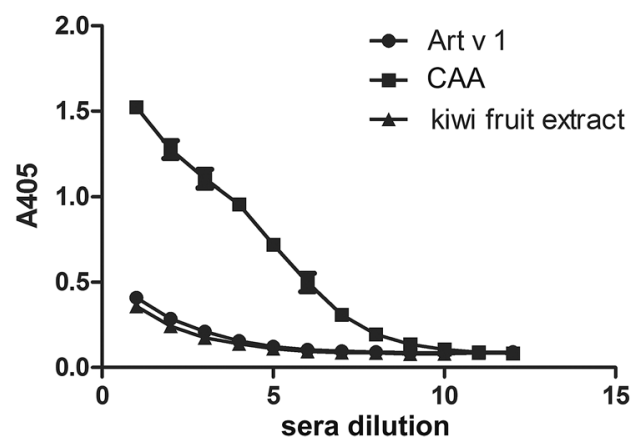

C

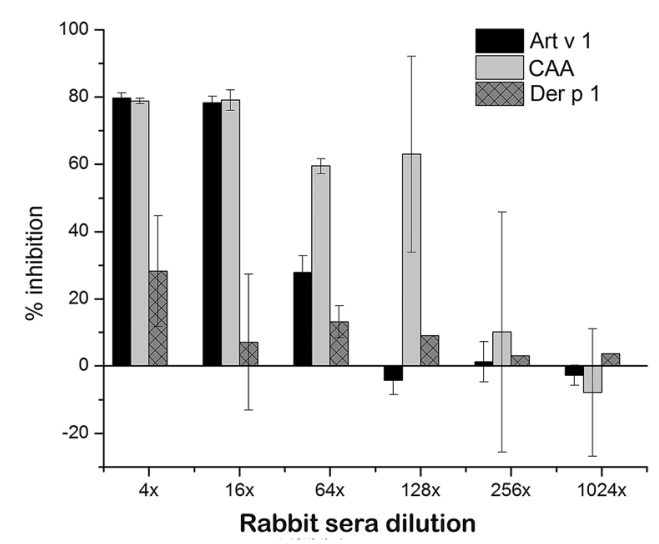

Fig. 5 Immunogenicity of Art $\vee 1$ and CAA in rabbits and blocking potential of rabbit antibodies raised to Art $v 1$ and CAA. Direct ELISA for detection of IgG binding from the sera of rabbits immunized by Art v 1 (circles) and CAA (squares) to plate coupled with (A) CAA and (B) Art v 1. Control series were done on the same plates with the rabbit antiserum raised against irrelevant kiwi fruit extract proteins (triangles). 12 double fold serial dilutions of rabbit sera were done. (C) Blocking capacity of rabbit antibodies, generated to Art $\vee 1, C A A$ and irrelevant extract, for IgE reactivity to Art $\vee 1$ in serum pools of mugwort pollen allergic patients. Pooled sera of mugwort pollen allergic patients (1.5 times diluted) were incubated with serial dilutions (4 to 1024) of rabbit antibodies, raised to Art v $1, C A A$ and kiwi extract as a control, and the remaining unblocked human IgE that binds to the Art $v 1$ coupled to the plate was detected. in an experiment of blocking of the binding of IgE from the serum pool of mugwort pollen allergic patients to the Art v 1coupled microtiter plate (Fig. 5C). At low sera dilutions (4 and 16), rabbits' anti-CAA and anti-Art $\mathrm{v} 1$ completely blocked human IgE binding to Art $\mathrm{v} 1$. At higher rabbit sera dilutions, anti-CAA exerted a higher blocking capacity ( $p<0.05$ ), implying that immunization with CAA resulted in the production of more efficient blocking antibodies of a slightly higher titer.

Immune response to Art $\mathrm{v} 1$ and CAA in C57BL/6 mice is similar in quantity and quantity of anti-Art $\mathrm{v} 1$ generated antibody subtypes

In order to test the immune response to Art $\mathrm{v} 1$ and its cis-aconityl derivative in a mouse model, C57BL/6 mice were immunized and Art v 1-specific IgE, total IgG, as well as IgG subtypes IgG1, IgG2a and IgG2b responses were analyzed by ELISA.

Our results demonstrate that both Art v 1 and CAA immunization only slightly increased IgE production (Fig. 6A and B). Both Art $v 1$ forms induced a significant $(p<0.05)$ increase in total IgG, and there was a tendency of CAA to induce a higher IgG response (Fig. 6C and D). These results demonstrate that the modified Art v 1 maintains the ability to suitably stimulate the immune system to produce specific IgG antibodies directed towards the native Art v 1 . Moreover, immunization of mice did not generate significant amount of IgE to CAA.

To get better insight into the differences in IgG responses between Art $\mathrm{v} 1$ and CAA, we have determined the IgG subtypes. Mice immunized with both Art $\mathrm{v} 1$ and CAA demonstrated significantly increased production of IgG1, compared to alum alone $(p<0.005)$, Fig. 7A and B. However, generation of IgG2a and IgG2b antibodies was not significantly increased in either Art v 1 or CAA-immunized mice (Fig. 7C-F).

\section{Assessing Art v 1 and CAA immunogenicity with a DC-derived endolysosomal degradome}

We applied an endolysosomal in vitro degradation assay with isolated total endolysosomal fractions from murine $\mathrm{DCs}^{14}$ to compare the susceptibility of CAA and Art $\mathrm{v} 1$ to endolysosomal proteases. We have used HRP as an internal reference to estimate proteolytic activity of the obtained microsomal preparation. The half-life of HRP $(1.5 \mathrm{~h})$ was found to be similar to the one that was obtained by Egger et al. ${ }^{19}$ using the same procedure for endolysosomal fraction preparation. Art $\mathrm{v} 1$ appeared to be very resistant to the endolysosomal proteases of DC, with a halflife of about $26 \mathrm{~h}$, in comparison to Bet v $1.401(3.8 \mathrm{~h})$ obtained by Egger $e t$ al. ${ }^{19}$ in a similar degradation system. CAA, with an average half-life of $40 \mathrm{~h}$, was slightly more resistant to degradation than Art v 1 (Fig. 8A and C).

We analyzed the most dominant high molecular mass peptides by high-resolution mass spectrometry, in order to compare degradation patterns of the native and modified Art $\mathrm{v}$ 1. Due to the extremely high diversity of hydrolyzed hydroxyproline-rich domain (Table S1 and Fig. S1 and S2 $\dagger$ ), it is difficult to map its degradation, but we were able to monitor the degradation of the less variable defensin domain (Fig. 8B, Table S2 and Fig. S3-S12†). After 15 min of endolysosomal processing, 
A

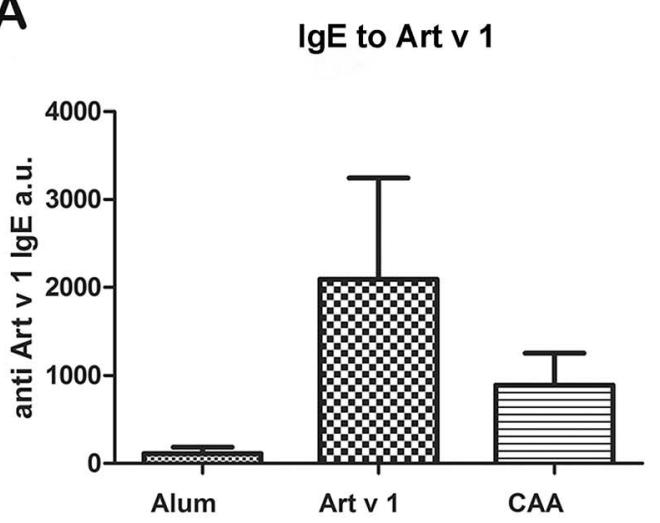

C $\quad \lg G$ to Art v 1

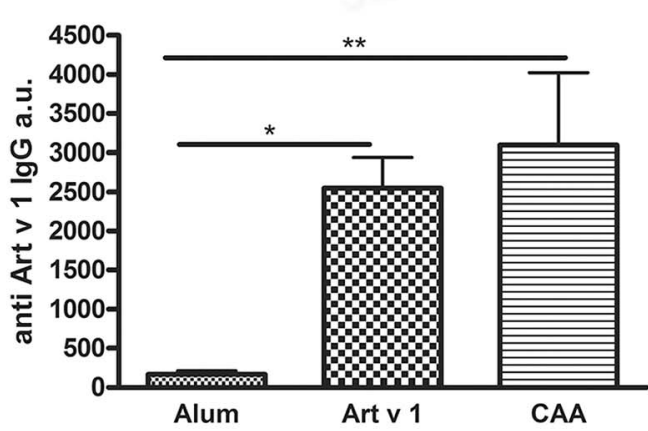

Art $\mathbf{v} 1$ coupled plates
B

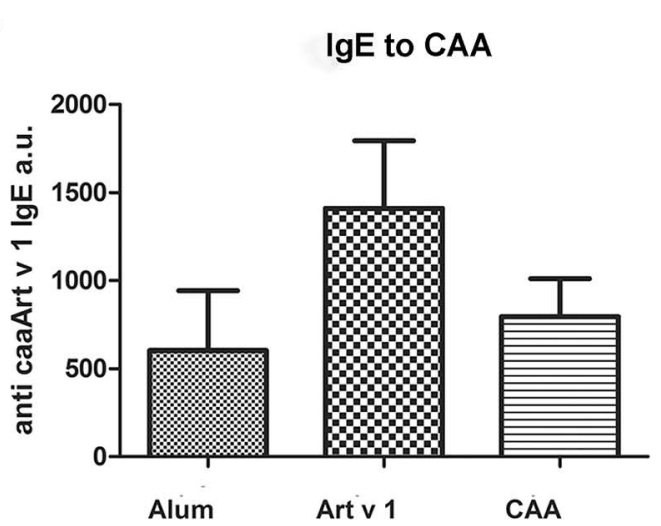

D IgG to CAA

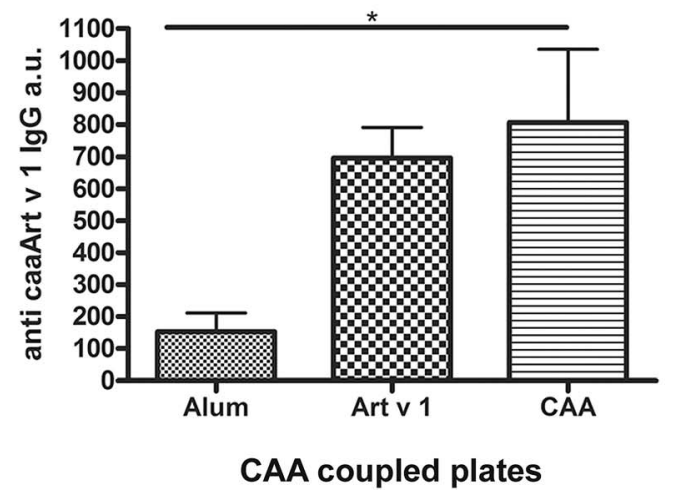

Fig. $6 \mathrm{IgG}$ and IgE responses in mice immunized with Art v 1, CAA and alum alone. Rabbit sera, obtained by immunization with Art v 1, CAA and alum alone, were tested in direct ELISA experiments. IgE levels were determined when plates were coupled with Art $v 1$ (A) or CAA (B), and IgG response was determined when plates were coupled with Art v 1 (C) or CAA (D). In parallel, positive anti-Art v 1 serum pool was serially diluted in order to estimate specific antibody arbitrary units. Statistical significance: **p 0.005 and $* p<0.05$.

the most dominant peptide, with the highest relative intensity, was peptide \#15 (5909 Da), originating from and containing the whole defensin domain, which is invariable in all Art v 1 isoforms (Fig. 8B). Its generation in the first minutes of processing suggests that the most proteolysis prone site on Art $\mathrm{v} 1$ is a small linker between defensin and the hydroxyproline-rich domain. Later on, this peptide becomes more and more shortened, and after $48 \mathrm{~h}$ the most dominant peptide is 19 (5566 Da), which consists of the whole defensin domain shortened by the $\mathrm{N}$ terminal Lys and C-terminal Cys, suggesting that the defensin domain is highly resistant to proteolytic degradation. Almost the same pattern was observed in Art v 1 and CAA, implying that acid-sensitive modification enabled undisturbed degradation by endolysosomal proteases. In fact, modifications of Lys residues impede recognition and action of enzymes, such as cathepsin $\mathrm{S},{ }^{19}$ favoring the cleavage of peptide bonds on the carboxyl side of the Lys residues.

The other peptides originating from the defensin domain, as shown in Fig. 8B and summarized in Table S3, $\dagger$ demonstrate that endolysosomal degradation of CAA and Art $v 1$ results in very similar peptide patterns, suggesting that CAA is capable of providing the same, or a very similar repertoire of MHC class II peptides for binding to T-cell receptors.

\section{Discussion}

In this study, we report the reversible modification of an allergen with the aim of reducing allergenicity while completely preserving allergen recognition by T-cells. The purified allergen, Art v 1, was modified with cis-aconitic anhydride, which reacts with free amino groups (lysine and free $\mathrm{N}$-terminus) on proteins similar to a reaction with other acid anhydrides, ${ }^{20}$ resulting in a monomeric modified protein that is able to bypass mucosal barriers if applied locally. ${ }^{21}$ However, cis-aconitylation is a reversible modification due to acyl group hydrolysis under acidic conditions, ${ }^{\mathbf{8 , 9 , 2 2}}$ and hence during processing in endolysosomal compartments, the allergen completely recovers its native structure.

It is known that IgE antibodies to Art v 1 are mostly directed against the defensin domain. ${ }^{17,23}$ By mapping the interactions between Art v 1 and human IgE antibodies, it was shown that IgE interaction sites on Art $\mathrm{v} 1$ are predominantly positively charged. ${ }^{12,16}$ cis-Aconitylation converts positively charged amino groups into double negative groups, hence resulting in a marked reduction in rabbit IgG and human IgE binding in applied ELISAs and ex vivo basophil degranulation assay. Although the modification did not result in a significant change 
A
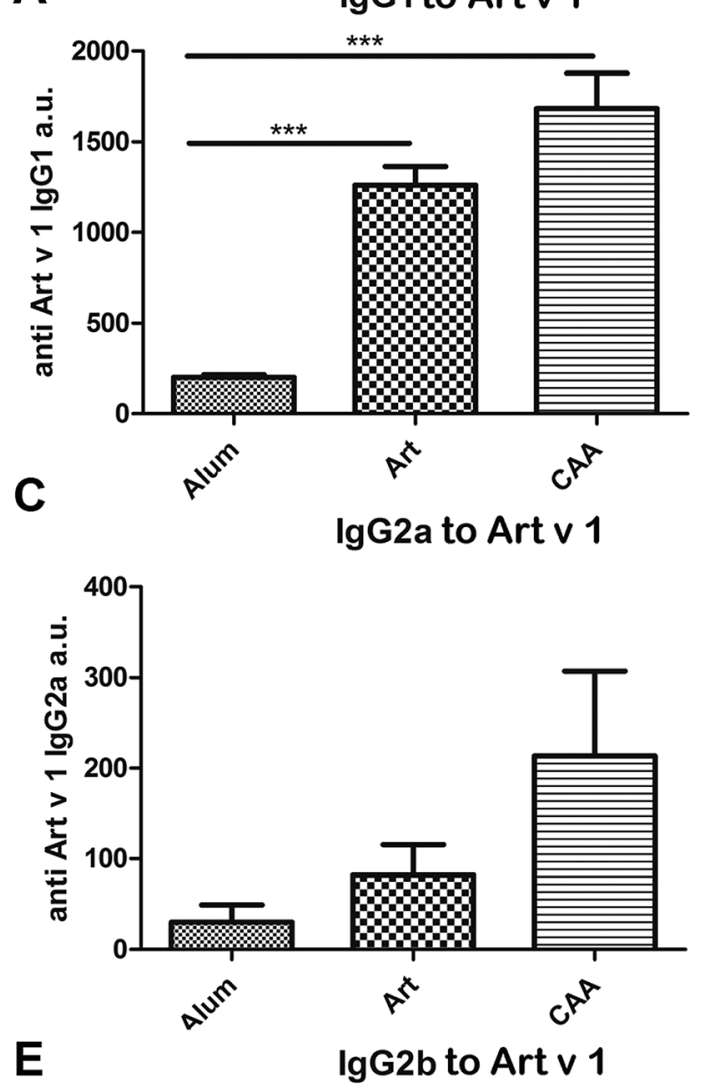

E

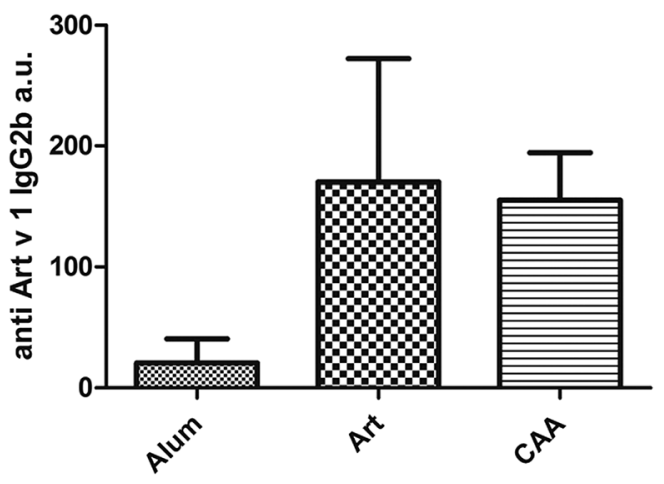

B

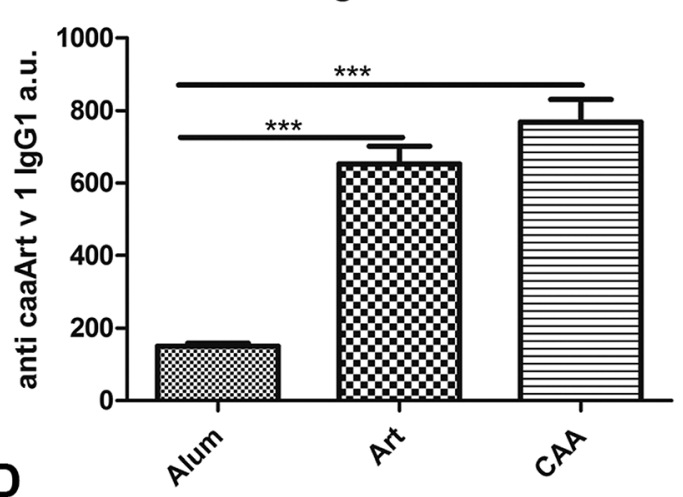

IgG2a to CAA
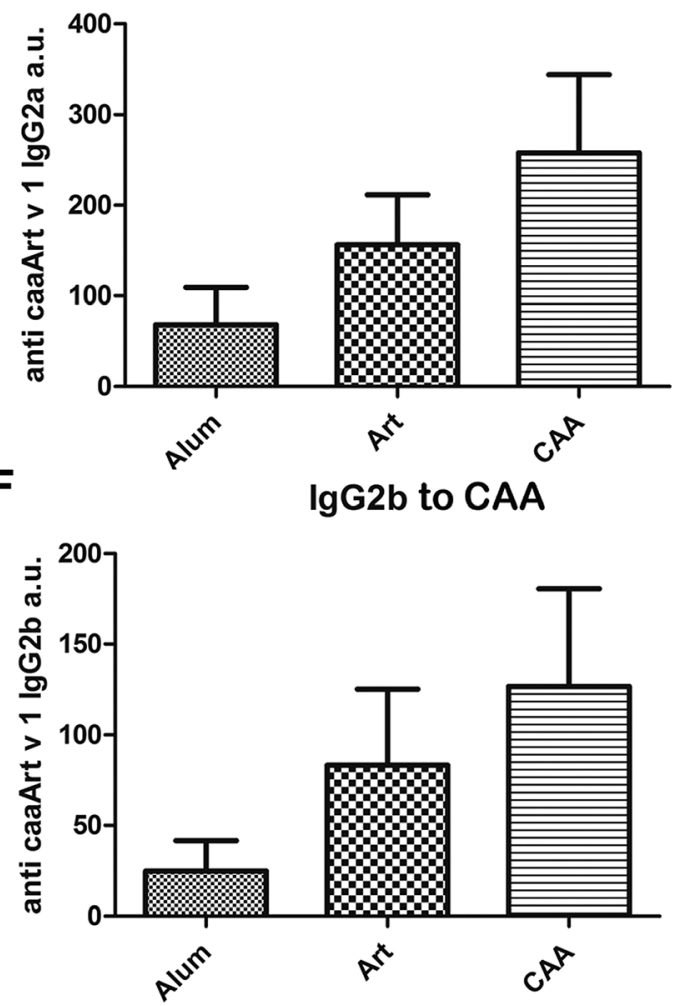

Fig. 7 IgG subtyping in mice immunized with Art v 1, CAA and alum alone. Rabbit sera, obtained by immunization with Art v 1 , CAA and alum alone, were tested in direct ELISA experiments. Plates are coupled with Art v 1 (A, C and E) for determination of IgG1, IgG2a and IgG2b levels, respectively, or with CAA (B, D and F) for determination of IgG1, IgG2a and IgG2b response, respectively. In parallel, positive anti-Art v 1 serum pool was serially diluted in order to estimate specific antibody arbitrary units. Statistical significance: $* * * p<0.001, * * p<0.005, * p<0.05$.

in protein folding, extensive acylation was efficient in reducing human IgE binding 10 to 575-times in ELISA inhibition with individual human sera.

Further, retaining immunogenicity in animals and the capacity to induce T-cells proliferation of the cis-aconitylated Art $\mathrm{v} 1$ derivative was demonstrated. Both Art v 1 and CAA induced antigen-specific proliferation of PBMCs from mugwort allergic donors. However, in contrast to Art v 1, which induced typical Th2 type cytokines, IL-4, IL-5 and IL-10, T-cell response to the CAA resulted in low cytokine production in PBMCs cultures. Nonprofessional APCs from PBMCs uptake antigens via IgE (e.g.
B-cells) and present them to T-cells. ${ }^{24}$ As CAA has a far lower affinity for IgE than Art v 1, it seems that inefficient uptake and presentation of CAA via B-cells provided a lower secretion of Th2 type cytokines. ${ }^{25,26}$

The rabbit IgG antibodies, induced by immunization with CAA, were capable of recognizing the native Art v 1 and effectively block human IgE binding to Art v 1. In mice, immunization with CAA led to a similar pattern of humoral immune response. An efficient immunogenicity of CAA may also be due to the more efficient uptake via scavenger receptors (SRs). SRs are expressed on macrophages, B-cells and DCs and recognize 
A

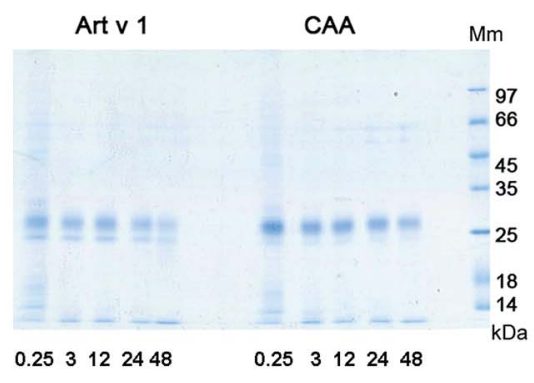

C

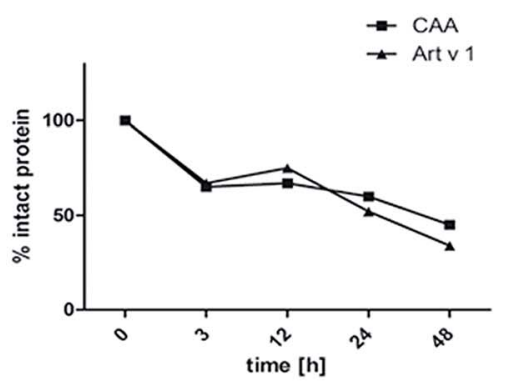

D

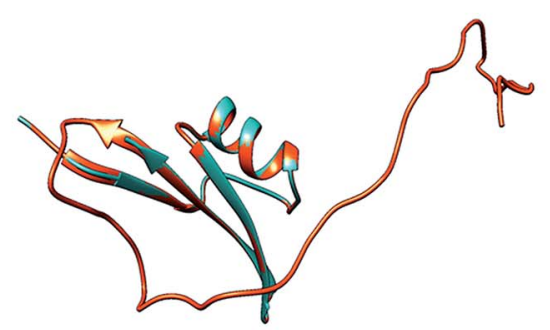

B

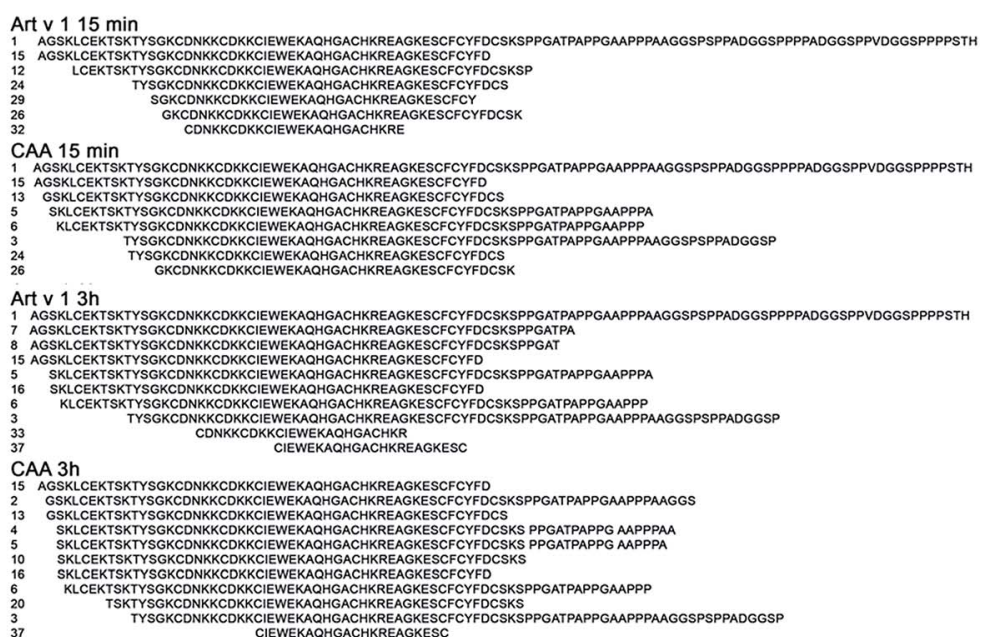

Art $v 112 h$

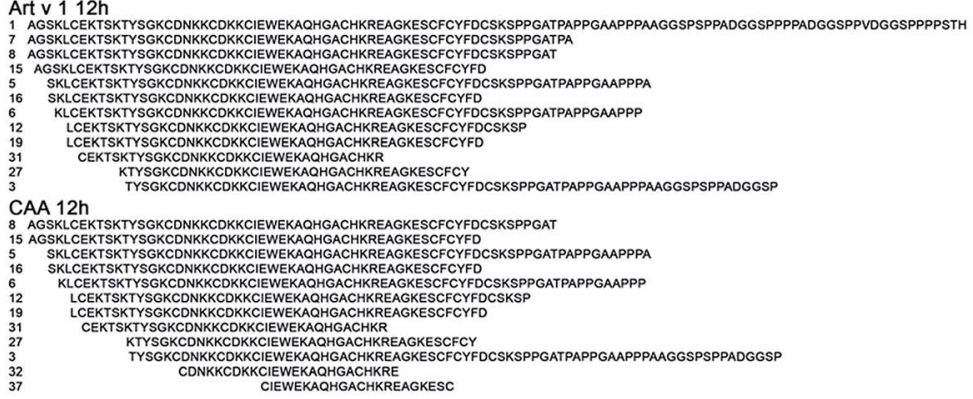

Art $v 124 \mathrm{~h}$ AGSKLCKKSKTYSGKCONKKCDKKCIEWEKAOHGACHKREAGKESCFCYFDCSKSPPGAT

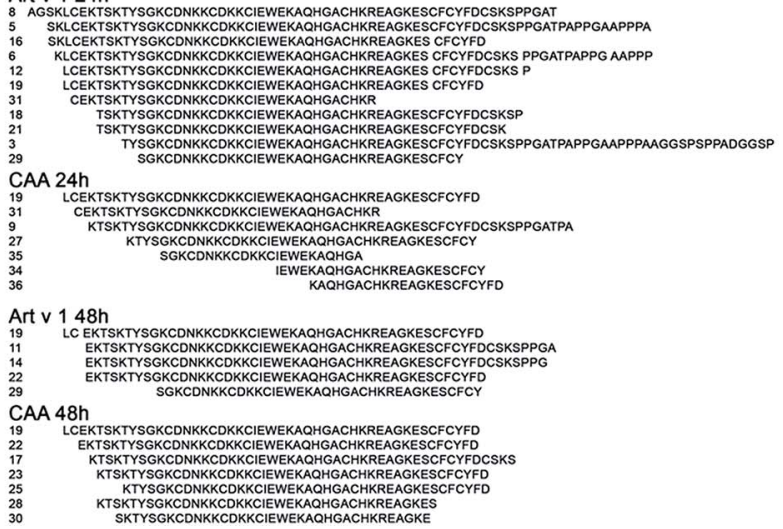

Fig. 8 Endolysosomal in vitro degradation of Art v 1 and CAA during $15 \mathrm{~min}, 3,12,24$ and $48 \mathrm{~h}$, using isolated total endolysosomal fractions from murine DCs. (A) Kinetics of endolysosomal degradation of Art $v 1$ and CAA monitored by SDS PAGE (under reducing conditions), (B) time course of liberation of peptides during endolysosomal degradation of Art $v 1$ and CAA, (C) remained intact protein (\%) during endolysosomal proteolysis of Art $v 1$ and CAA, calculated from densitometrically quantified protein bands, (D) 3D model of Art v 1 (red), based on NMR structure of Art v 1 (PDB entry 2KPY), overlapped with peptide number 15 identified after $15 \mathrm{~min}, 3 \mathrm{~h}$ and $12 \mathrm{~h}$ of endolysosomal degradation of Art $v 1$ and $\mathrm{CAA}$ (blue).

diverse polyanionic ligands, ${ }^{27}$ including many proteins modified by acylation to enhance their negative charge..$^{\mathbf{8 , 2} 8}$

It is known that DCs and macrophages are more efficient APCs than B-cells and monocytes of PBMCs, and those APCs from PBMCs are not the actual target APCs for allergen-specific immunotherapy. ${ }^{29}$ Thereby, in-depth analysis of endolysosomal processing of CAA was undertaken in an in vitro degradome system obtained from dendritic cells. After endolysosomal in vitro degradation, almost the same peptide pattern was observed in Art v 1 and CAA, implying that the applied reversible modification enabled a similar degradation by endolysosomal proteases. It is known that antigens displaying a weak capacity for T-cell priming in vivo were highly susceptible to endolysosomal proteases in vitro. ${ }^{19}$ Art v 1 harbors only a single immunodominant T-cell epitope (25-36) in the defensin domain and is recognized by $85 \%$ of the Art $\mathrm{v}$ 1-reactive mugwort pollen allergic patients. ${ }^{30}$ Epitope mapping of T-cells demonstrated that 14 of 17 patients recognized an Art v 1 epitope in the region 22-36, while five patients recognized an epitope contained in the 43-54 region. ${ }^{31}$ In our study of the 37 peptides found, region 22-36 was completely retained in 34 identified peptides and region $43-54$ in 18 peptides. 
Disulfide bonds stabilizing typical $\alpha / \beta$ folding of the Art $\mathrm{v} 1$ defensin domain ${ }^{32}$ are arranged with one (C6-C53) external, and three internal disulfides which criss-crossed each other (C17-C37, C22-C47, and C26-C49), resulting in a central defensin region that was more tightly packed and less accessible to proteolytic enzymes. This can explain why we found that most of the degradation resistant peptides are contained in this region and preferably present the immunodominant peptide. Moreover, it was demonstrated that IgE-binding to the Art v 1 single cysteine mutants, C6S and C53S, was almost completely retained, ${ }^{16}$ while complete loss or only marginal IgE reactivity was observed upon disruption of disulfide bonds C22-C47, C26-C49, or C17-C37, supporting the existence of a tightly packed internal core important for epitope formation, and being hardly accessible to enzyme attack. Under the applied conditions (presence of $2 \mathrm{mM}$ DTT) there was limited reduction, and it appeared that the C6-C53 disulfide was most prone to reduction, which allowed protease to attack up to the internal core, but not the core itself. In the endolysosomal system of APCs, where some of the reductive processes occur, ${ }^{33}$ the same destiny of the defensin domain could be expected.

In this study, the strategy was focused on the temporary masking of defensin domain epitopes to abrogate IgE binding and also the preservation of the structural motifs necessary for T-cell recognition. Our acid environment-responsive modification aims to deliver epitopes of native Art v 1, by releasing them within a particular site. Therefore this approach can be considered as a "smart" drug delivery system that is able to deliver a therapeutically effective dose in a controlled manner, while minimizing adverse side effects.

There are several advantages to this approach that greatly improve the safety and efficiency of AIT. Firstly, modification results in reduced specific IgE binding, providing reduced allergenic activity and improved safety of allergen vaccine. Secondly, the reversibility of the modification enables the conversion of a modified protein to a native, immunologically fully active, allergen, providing high efficiency and safety. Third, in spite of the reversibility of the modification, the obtained allergen derivative is stable in neutral conditions and it is transformed to the native allergen only in the lysosomal compartment, under the control of intracellular acidification in APCs, where it is degraded.

Preservation of the allergen monomeric molecular size will enable its application in local immunotherapy, in addition to the traditional, subcutaneous application route. Applications of organic acid anhydrides, which are highly reactive and readily transform into organic acids with very low toxicity, further ensure safe preparation.

\section{Conclusions}

Herein, an acid-sensitive modification of an allergen, which enables the selective blockage of IgE-binding epitopes and reduction of the protein allergenicity without affecting the T-cell epitopes, protein folding, immunogenicity and capacity to mount an immune response to the level of unmodified protein, is described. The approach described in this study efficiently targeted subcellular compartment directed conversion of an acid-sensitive scaffold for a modified protein, enabling the controlled release of a native allergen, while bypassing IgE antibodies and effector mechanism in the allergy. This approach opens up new opportunities in the creation of safe and effective allergovaccines where immunogenicity is fully retained, in contrast to irreversible modifications. Moreover, this approach can be applied to quickly and efficiently improve the safety of any AIT strategy, as it can be applied to purified proteins, native allergenic extracts or allergens produced by recombinant technology.

\section{Conflict of interest}

The authors declare no conflict of interest.

\section{Acknowledgements}

This work was supported by grant No. OI 172024 of the Ministry of Education, Science and Technological Development of the Republic of Serbia and FP7 RegPot project FCUB ERA GA No. 256716. The EC does not share responsibility for the content of the article.

\section{References}

1 M. Akdis, World Allergy Organ. J., 2014, 7, 23.

2 K. Marth, M. Focke-Tejkl, C. Lupinek, R. Valenta and V. Niederberger, Curr. Treat. Options Allergy, 2014, 1, 91-106.

3 L. Jongejan and R. van Ree, Curr. Allergy Asthma Rep., 2014, 14, 478.

4 K. J. Mackenzie, P. M. Fitch, M. D. Leech, A. Ilchmann, C. Wilson, A. J. McFarlane, S. E. Howie, S. M. Anderton and J. Schwarze, Immunology, 2013, 138, 258-268.

5 E. E. Weinberger, M. Himly, J. Myschik, M. Hauser, F. Altmann, A. Isakovic, S. Scheiblhofer, J. Thalhamer and R. Weiss, J. Controlled Release, 2013, 165, 101-109.

6 G. Passalacqua, M. Pasquali, R. Ariano, C. Lombardi, A. Giardini, I. Baiardini, G. Majani, P. Falagiani, M. Bruno and G. W. Canonica, Allergy, 2006, 61, 849-854.

7 V. M. Leb, B. Jahn-Schmid, K. G. Schmetterer, H. J. Kueng, D. Haiderer, A. Neunkirchner, G. F. Fischer, K. Nissler, A. Hartl, J. Thalhamer, B. Bohle, B. Seed and W. F. Pickl, J. Allergy Clin. Immunol., 2008, 121, 64-71.

8 K. Shakushiro, Y. Yamasaki, M. Nishikawa and Y. Takakura, Immunology, 2004, 112, 211-218.

9 D. Stanic, L. Burazer, M. Gavrovic-Jankulovic, R. M. Jankov and T. C. Velickovic, J. Serb. Chem. Soc., 2009, 74, 359-366.

10 M. Blanusa, I. Perovic, M. Popovic, N. Polovic, L. Burazer, M. Milovanovic, M. Gavrovic-Jankulovic, R. Jankov and T. Cirkovic Velickovic, J. Chromatogr. B: Anal. Technol. Biomed. Life Sci., 2007, 857, 188-194.

11 N. Harboe and A. Ingild, Scand. J. Immunol., Suppl., 1973, 1, 161-164.

12 I. Perovic, M. Milovanovic, D. Stanic, L. Burazer, D. Petrovic, N. Milcic-Matic, G. Gafvelin, M. van Hage, R. Jankov and T. Cirkovic Velickovic, Clin. Exp. Allergy, 2009, 39, 435-446. 
13 R. K. Gupta, Adv. Drug Delivery Rev., 1998, 32, 155-172.

14 M. Stojadinovic, R. Pieters, J. Smit and T. Cirkovic Velickovic, Toxicol. Sci., 2014, 140, 224-235.

15 U. K. Laemmli, Nature, 1970, 227, 680-685.

16 G. Razzera, G. Gadermaier, V. de Paula, M. S. Almeida, M. Egger, B. Jahn-Schmid, F. C. L. Almeida, F. Ferreira and A. P. Valente, Structure, 2010, 18, 1011-1021.

17 M. Himly, B. Jahn-Schmid, A. Dedic, P. Kelemen, N. Wopfner, F. Altmann, R. van Ree, P. Briza, K. Richter, C. Ebner and F. Ferreira, FASEB J., 2002, 16, 106-108.

18 G. Gadermaier, B. Jahn-Schmid, L. Vogel, M. Egger, M. Himly, P. Briza, C. Ebner, S. Vieths, B. Bohle and F. Ferreira, Mol. Immunol., 2010, 47, 1292-1298.

19 M. Egger, A. Jurets, M. Wallner, P. Briza, S. Ruzek, S. Hainzl, U. Pichler, C. Kitzmuller, B. Bohle, C. G. Huber and F. Ferreira, PLoS One, 2011, 6, e17278.

20 T. Cirkovic, M. Gavrovic-Jankulovic, S. Prisic, R. M. Jankov, L. Burazer, O. Vuckovic, Z. Sporcic and S. Paranos, Allergy, 2002, 57, 1013-1020.

21 N. Shershakova, E. Bashkatova, A. Babakhin, S. Andreev, A. Nikonova, I. Shilovsky, O. Kamyshnikov, A. Buzuk, O. Elisyutina, E. Fedenko and M. Khaitov, PLoS One, 2015, 10, e0135070.

22 K. Takahashi, J. Biochem., 1977, 81, 641-646.
23 A. Dedic, G. Gadermaier, L. Vogel, C. Ebner, S. Vieths, F. Ferreira and M. Egger, Mol. Immunol., 2009, 46, 416-421.

24 M. I. Yuseff, P. Pierobon, A. Reversat and A. M. LennonDumenil, Nat. Rev. Immunol., 2013, 13, 475-486.

25 D. M. Lindell, A. A. Berlin, M. A. Schaller and N. W. Lukacs, PLoS One, 2008, 3, e3129.

26 L. Y. Drake, K. Iijima, K. Hara, T. Kobayashi, G. M. Kephart and H. Kita, PLoS One, 2015, 10, e0121660.

27 H. Zhang, Y. Yang and U. P. Steinbrecher, J. Biol. Chem., 1993, 268, 5535-5542.

28 M. E. Haberland and A. M. Fogelman, Proc. Natl. Acad. Sci. U. S. A., 1985, 82, 2693-2697.

29 H. Kahlert, E. Grage-Griebenow, H. T. Stuwe, O. Cromwell and H. Fiebig, J. Immunol., 2000, 165, 1807-1815.

30 B. Jahn-Schmid, G. F. Fischer, B. Bohle, I. Fae, G. Gadermaier, A. Dedic, F. Ferreira and C. Ebner, J. Allergy Clin. Immunol., 2005, 115, 399-404.

31 B. Jahn-Schmid, P. Kelemen, M. Himly, B. Bohle, G. Fischer, F. Ferreira and C. Ebner, J. Immunol., 2002, 169, 6005-6011.

32 B. P. H. J. Thomma, B. P. A. Cammue and K. Thevissen, Planta, 2002, 216, 193-202.

33 D. S. Collins, E. R. Unanue and C. V. Harding, J. Immunol., 1991, 147, 4054-4059. 